Available online on 15.07.2020 at http://ujpr.org
Universal Journal of Pharmaceutical Research
An International Peer Reviewed Journal
Open access to Pharmaceutical research is an open access article distributed under the terms of the Creative Commons Attribution-Non
Commercial Share Alike 4.0 License which permits unrestricted non commercial use,
provided the original work is properly cited
Volume 5, Issue 3, 2020

\title{
PREVALENCE AND CAUSES OF TRAUMATIC DENTAL INJURIES TO ANTERIOR TEETH AMONG PRIMARY SCHOOL CHILDREN IN SANA'A CITY, YEMEN
}

Noha Jamal Ahmed Mutaher ${ }^{1}\left(\mathbb{D}\right.$, Khaled A AL-Haddad $^{1}\left(\mathbb{D}\right.$, Ameen Abdullah Yahya Al-Akwa1 ${ }^{1}$, Mohammed A Al-labani ${ }^{1}{ }^{1}$, Hassan Abdulwahab Al-Shamahy ${ }^{2}{ }^{\circ}$, Abdul Qader Mohammed Qasem Zabara $^{1}(1)$, Hussien Mohammed Shogaa Al-deen ${ }^{1}(\mathbb{D}$

${ }^{l}$ Orthodontics, Pedodontics and Prevention Department Faculty of Dentistry, Sana'a University, Yemen. ${ }^{2}$ Departement of Basic Sciences, Faculty of Dentistry, Sana'a University, Republic of Yemen.

\section{ABSTRACT}

Objectives: The current study was conducted to reveal the prevalence and causes of traumatic dental injuries to permanent anterior teeth among mixed dentition of schoolchildren in Sana'a City, Yemen.

Methods: A cross-sectional study was performed on 1252 schoolchildren aged 7-12 years in three districts of Sana'a city, Yemen. They numbered 700 males and 552 females from 26 randomly selected public and private schools. Clinical examination of permanent anterior teeth was done according to the classification of Ellis modified by Fried.

Results: Prevalence of TDI was $10.30 \%$, with a male ratio of 4.8 : female $1,(P<0.05)$. Most of the children suffered only one damage to the tooth and most of them are in the maxillary central incisors. The TDI increased with older age (10-12 years old) $(16.5 \%)$ with odds ratio 4.8, $(p<0.05)$. Regarding the site of trauma, most injuries happened in males on the street $(44.9 \%)$ while in females happened at home (31.81\%) and falls were the main cause of TDI. In both sexes, the most common type of injury was class I (enamel fracture) followed by class II (enamel and dentine without pulp involvement).

Conclusion: In conclusion, the prevalence of TDI in permanent anterior teeth among mixed dentition of school children in Sana'a was high, higher in males than in females, with a peak age of 10 to 12 years, falls was the common cause, and occurred mostly on the street for boys and home for females. Accordingly, educational programs should be developed that focus on ways to prevent dental trauma and the benefits of seeking urgent treatment to maintain avulsed and fractured teeth.

Keywords: permanent anterior teeth, prevalence, schoolchildren, traumatic dental injuries, TDI, Yemen

Article Info: Received 13 April 2020; Revised 28 May; Accepted 31 June, Available online 15 July 2020

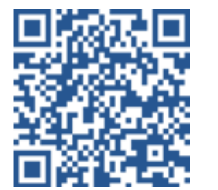

\section{Cite this article-}

Mutaher NJA, AL-Haddad KA, Al-Akwa AAY, Al-labani MA, Al-Shamahy HA, Zabara AQMQ, Al- deen HMS.

Prevalence and causes of traumatic dental injuries to anterior teeth among primary school children in Sana'a city, Yemen. Universal Journal of Pharmaceutical Research 2020; 5(3):38-43.

DOI: https://doi.org/10.22270/ujpr.v5i3.414

Address for Correspondence:

Prof. Hassan A. Al-Shamahy, Departement of Basic Sciences, Faculty of Dentistry, Sana'a University, Republic of Yemen, Tel: +967-1-239551, E-mail: shmahe@yemen.net.ye

\section{INTRODUCTION}

The child is progressively developing, mentally and physically, characterized by constant change or vigorous activity. Child searches for the ocean, trying to explore, so child 's more likely to fall and be injured. Child quality of life is severely affected by her/his health, especially painful injuries that may directly affect aspects of speech, nutrition, social interaction and psychology ${ }^{1}$. Traumatic tooth injury represents a sharp transfer of energy to the tooth and its sustaining structures, consequential in a fracture and/or displacement of the tooth and the disjointing or crushing of the supporting tissues (gums, periodontal ligament and bone) $)^{2}$.
Dental injuries can be caused by an indirect or direct trauma. When the tooth itself is struck, direct trauma occurs. An indirect shock occurs as the lower tooth arch is firmly closed in contrast to the upper part, for instance, a blow to the chin. Direct trauma involves damages in the anterior region, whilst indirect trauma prefers crown or crown root fractures in the premolar and molar regions with the probability of jaw fractures in the condylar regions and symphysis ${ }^{3}$. In permanent teeth, traumatic injuries have been reported to obtain a prevalence rate of $4.1 \%$ to $58.6 \%$. The large difference in reported rates can be recognized to several different factors, including study types, trauma classification, methodology, study size and population, differences in 
cultural behavior and geographical location ${ }^{4}$. Traumatic injuries are the third-largest cause for teeth loss after the caries and periodontal causes and are still on the rise ${ }^{5}$. There is agreement by researchers that traumatic injuries happen more frequently to the upper jaws than to the lower incisors and that the central incisors are more affected than the lateral incisors ${ }^{6}$. The most common causes of these injuries are falls, sports, biking, and traffic accidents. Factors predisposing to dental trauma can be associated with a person's anatomical features such as increased overjet, or insufficient lip covering of the upper front teeth ${ }^{7,8}$. TDI to primary teeth may finally lead to problems with primary permanent teeth, for instance hypoplasia, discolouration, delayed eruption time, and tooth malformation ${ }^{9}$. Delayed treatment of dental injuries in children is common in many countries. This can be attributed to various factors such as short-lived primary teeth, and the lack of attention required because the child may not show any associated signs or symptoms ${ }^{10}$. Trauma is not always predictable, but a proportion of injuries can be prevented if risk factors are understood and widespread public awareness allowing the development of necessary preventive strategies to improve planning, decision-making and intervention. Its results can help plan effective educational programmers targeting teachers, school children, and parents. Education should be widely provided to individuals who supervise and care for children and who will be near the scene of the traumatic dental injury (TDI) ${ }^{11}$. There are few reports available on epidemiology of child dental injuries in developing countries, especially when compared to epidemiological data on tooth decay and periodontal disease $^{12}$.There is a scarcity of epidemiological data on the prevalence of dental trauma among schoolchildren compared to tooth decay in Yemen. There was only one published data on TDI among schoolchildren in Sana'a, conducted by Al Akwa in 2009. Therefore, this research aimed to study the prevalence and causes of traumatic dental injuries to the anterior teeth among schoolchildren in Sana'a (the Yemeni capital) because dental trauma is a public health concern in Yemen.

\section{SUBJECTS AND METHODS}

Study Design: A cross sectional study was conducted. Study Area: The study was done at public and private schools in Sana'a City, which is the capital city of Yemen, located in the center of it. Sana'a consists of ten districts. Three districts were chosen, randomly selected, from the south Al-Safia District, from the nourth Al-Thwarh District and from the middle Old Sana'a District.

Study Population: The target population was students of both genders, aged 7-12 years, chosen from public and private primary schools that are located in the three districts.

Inclusion Criteria were all primary public and private schools located in these three districts; and students of both genders with average age of 7-12 years old. However, the exclusion criteria were non-Yemeni children, children with traumatic dental injuries in primary teeth; Children with a type of mental anomaly or systemic disease such as epilepsy patients; and/or child with anterior teeth with flurosis and caries.

Sampling Technique: The sample size was calculated using version 7 of the EPI, based on the following assumptions: 1-Reference students aged 7 to 12 years in three regions according to the Education Office, 2018 in Sana'a was 50,400. 2-Rates of traumatic dental injuries are expected at 50\%. 3- Confidence limit $=3 \%$. 4- Confidence level $=97 \%$, so the calculated sample size was 1252.

Sampling Type: Multistage sampling method which the first Stage: from the ten districts we chosen randomly three districts from the south Al-Safia District, from the north Al-Thwarh District and from the middle Old Sana'a District. The second stage: in each district, we considered that all private and public schools are included in the study, then we randomly selected sixteen public schools and ten private schools which represent nearly $10 \%$ of total number of schools according to Education, 2018. The Third stage: In all randomly selected school, we considered that all the classes of students aged from 7 to12 years old are included in the study. Then we randomly selected one class from each level. Finally, all the students in each class were included in the study. Selection from the selected classes was systemically random; so that we can reach the sample size target

Data Collection: Data was collected by face-to-face interviews. The Structured questionnaire was about age, gender, cause of injury, place of injury, type of injury and the tooth involved.

Methods of Examination: Before starting the study, and after it was approved by the Faculty of Dentistry in Sana'a University, ethical matters were taken into considerations. The examination was conducted with permission from the education authorities. Permission was obtained from the Office of Education and the principals of the respective schools, and after obtaining informed consent from parents of the participating children. Clinical examination was performed using a regular oral mirror and gloves. The necessary tools and materials were packed and sterilized in sufficient quantities for each working day.

Dental examination included only the teeth of the permanent upper and lower permanent incisors. The Federation Dentaire International System (FDIS) was used to record the number of all accidental damaged teeth. The examined child was sitting in a straight chair and near the window to use natural daylight during the examination. Dental injuries and hard tissue fractures are classified according to the Modification of the Ellis Classification $^{13}$ as follows:

Class I: Simple fracture of enamel only

Class II: Fracture includes enamel and dentine

Class III : Fracture includes enamel, dentine and small pulpal exposure

Class IV: Fracture involves a significant amount of pulpal exposure

Class V: Fracture involves complete loss of tooth (avulsion)

Class VI : A root fracture 


\section{Data analysis}

The data was statistically analyzed using SPSS 21 . The data were presented by using tables and figures. Percentage (\%) was used to describe the qualitative variables. Pearson's Chi-Square test was used to show the significance of the association between the outcomes at the level of significance less than $0.05(\mathrm{P})$.

Table 1: Distribution of the sample by age and gender.

\begin{tabular}{ccccccc}
\hline \multirow{2}{*}{$\begin{array}{c}\text { Age in } \\
\text { years }\end{array}$} & \multicolumn{9}{c}{ Female } & \multicolumn{2}{c}{ Male } & \multicolumn{2}{c}{ Total } \\
& $\mathbf{N}$ & $\boldsymbol{\%}$ & $\mathbf{N}$ & $\boldsymbol{\%}$ & $\mathbf{N}$ & $\boldsymbol{\%}$ \\
\hline $7-9$ & 272 & 49.28 & 345 & 49.29 & 617 & 49.28 \\
$10-12$ & 280 & 50.72 & 355 & 50.71 & 635 & 50.72 \\
Total & 552 & 100.0 & 700 & 100.0 & 1252 & 100.0 \\
\hline
\end{tabular}

\section{RESULTS}

This study was conducted on 1252 schoolchildren, 700 males and 552 females. The children were divided into two age groups 7-9 and 10-12 years as shows in Table 1. Trauma was found in 129 children $(10.30 \%) ; 107$ males $(15.28 \%)$ out of 700 and 22 females $(3.98 \%)$ out of 552 with ratio of approximately (male: female) of 4.8:1. There was a statically significant association between traumatic injury and gender. Males were associated OR 4.3 times (95\% $\mathrm{CI}=2.7-7.1)$ more prone to traumatic dental injuries compared to females $(p<0.001)$ as illustrates in Table 2. The number of traumatized teeth was 155 , (103 children had a single traumatized tooth, and 26 children had multiple traumatized teeth), but there was no statistically significant difference between gender and the number of traumatized teeth as illustrates in Table 3. The results revealed a significant statistical correlation between gender and location of injuries among school children. Most injuries of 129 children occurred at street $(41.6 \%)$, followed by home $(37.9 \%)$, school $(16.3 \%)$ and then park (3.9\%). Most injuries in males occurred at street (44.9\%) out of 107 and in females at home $(31.81 \%)$ out of 22 , as shows in Figure 1 . The most leading cause of injury in both genders was falling $(62.01 \%)$ out of 129 traumatic children. For males, falling was the leading cause $(59.8 \%)$ out of 107 , followed by sport $(21.5 \%$ of which 23 children were involved in football accidents), then traffic $(10.3 \%)$, after that violent fighting $(6.5 \%)$, and finally collisions with people or inanimate objects (1.9\%). For females, the chief cause was falling $(72.7 \%)$ out of 22 , followed by sport (18.2\%), and finally collisions and traffic $(4.5 \%)$. The girls did not suffer from injuries caused by violent fighting as shown in Figure 2. The results presented that the tooth most affected was the upper left central incisor $(44.96 \%)$, followed by upper right central incisor (37.49\%), then lower left Central incisor $(5.75 \%)$. Both lower right central incisor and upper right lateral incisor were $(2.8 \%)$ and both lower right and left lateral incisors were (1.55) as shows in Figure 3 . The distribution of dental injuries according to the classification of Ellis modified by Fried showed that the most common type of injury was enamel fracture $(51.6 \%)$, followed by enamel and dentine (36.1), then enamel and dentine with extensive exposure of pulp $(7.1 \%)$, then fracture involving complete loss of tooth (avulsion) (2.6\%),followed by enamel and dentine with early exposure of pulp (1.9\%) , and finally a root fracture $(0.6 \%)$ and no statistical significant difference between them and gender (Table $5)$.

Table 2: Prevalence of trauma among gender.

\begin{tabular}{|c|c|c|c|c|c|c|c|c|c|c|}
\hline \multirow{3}{*}{ Gender } & \multicolumn{4}{|c|}{ Traumatic cases } & \multirow[t]{3}{*}{ Total } & \multirow[t]{3}{*}{$X^{2}$} & \multirow[t]{3}{*}{$P$-value } & \multirow[t]{3}{*}{ OR } & \multirow{2}{*}{\multicolumn{2}{|c|}{$C I$}} \\
\hline & Yes & & & & & & & & & \\
\hline & Freq. & $\%$ & Freq. & $\%$ & & & & & Lower & Upper \\
\hline Male & 107 & 15.29 & 593 & 84.71 & 700 & 42.6 & $<0.001^{*}$ & 4.3 & 2.7 & 6.9 \\
\hline Female & 22 & 3.99 & 530 & 96.01 & 552 & & & Ref & & \\
\hline
\end{tabular}

*Based on Pearson's Chi-Square test. Significant at $P$ - value $<0.05$, OR: Odd Ratio, CI: Confidence Interval, Ref: Reference Value

Table 3: Association between numbers of traumatized teeth among gender.

\begin{tabular}{|c|c|c|c|c|c|c|c|}
\hline \multirow{3}{*}{$\begin{array}{l}\text { The } \\
\text { Tooth }\end{array}$} & \multicolumn{4}{|c|}{ Gender } & \multirow[b]{3}{*}{ Total } & \multirow{3}{*}{$\mathbf{X}^{2}$} & \multirow{3}{*}{$\begin{array}{c}P \text { - } \\
\text { value }\end{array}$} \\
\hline & \multicolumn{2}{|c|}{ Male } & \multicolumn{2}{|c|}{ Female } & & & \\
\hline & Freq. & $\%$ & Freq. & $\%$ & & & \\
\hline Single & 84 & 81.55 & 19 & 18.6 & 103 & 121 & $03^{*}$ \\
\hline Multiple & 46 & 88.5 & 6 & 11.5 & 52 & & \\
\hline
\end{tabular}

\section{DISCUSSION}

A traumatic tooth injury (TDI) is not a consequence of the disease but a result of particular factors that accumulate throughout life if not treated properly. Age was chosen between 7-12 years in this study, where during this period there is the maximum physiological growth and development in the life cycle of children whose activities mostly occur in the outdoor ${ }^{14}$. TDI that includes only anterior teeth may not only restrict biting, phonetics, and aesthetics but also have an impact on a child's personality and quality of life. Of the 1252 students from 7 to 12 years examined in
Sana'a, 129 children (10.3\%) suffer from traumatic dental injuries to the front teeth. This result was higher than other studies previously conducted among schoolchildren in Yemen, India, Iraq, and Jordan ${ }^{15-19}$. However, the current result almost agrees with studies in Africa, Tamilnadu and India by Govindarajan et al., ${ }^{20}$; Kulkarni and Raje ${ }^{21}$; and Ogordi et al., ${ }^{22}$. The difference in TDI prevalence is associated with many factors for instance study design, sample size, sampling procedure, diagnostic criteria, limited age groups, geographical differences and study locations ${ }^{23}$. On the other hand, many studies showed higher results than 
the current study (up to $58 \%$ ) 5,24 . The current study showed that out of 129 children with dental injuries, $107(82.9 \%)$ were males and $22(17.1 \%)$ were females at approximately 4.8: 1 (Table 2).

The gender difference was statistically significant, which coincides with most previous studies ${ }^{12,25,26,27}$. The cause of increased trauma among boys is their participation in recreational and sports activities or because of their more aggressive nature than girls, and the rates of puberty growth in boys and girls are more mature in nature ${ }^{14,28}$. However, in studies by Rajesh $e t$ $a l .{ }^{29}$, and Ain et al. ${ }^{30}$ there was no significant difference in TDI between male and female, and this result may be due to social changes in the study area that have led to increased participation of girls in sports, which can lead to dental injuries.

Table 4: The distribution of TDI according to the age groups.

\begin{tabular}{|c|c|c|c|c|c|c|c|c|c|c|}
\hline \multirow{3}{*}{$\begin{array}{c}\text { Age } \\
\text { Groups }\end{array}$} & \multicolumn{4}{|c|}{ Traumatic cases } & \multirow{3}{*}{ Total } & \multirow[t]{3}{*}{$\mathbf{X}^{2}$} & \multirow[t]{3}{*}{$P$-value } & \multirow[t]{3}{*}{ OR } & \multirow{2}{*}{\multicolumn{2}{|c|}{$95 \% \mathrm{CI}$}} \\
\hline & Yes & & No & & & & & & & \\
\hline & Freq. & $\%$ & Freq. & $\%$ & & & & & Lower & Upper \\
\hline $7-9 Y$ & 24 & 3.9 & 593 & 96.1 & 617 & 54.1 & $<0.001^{*}$ & & Ref & \\
\hline $10-12 Y$ & 105 & 16.5 & 530 & 83.5 & 635 & & & 4.8 & 3.1 & 7.9 \\
\hline
\end{tabular}

*Based on Pearson's Chi-Square test, Significant at $P$-value<0.05, OR: Odd Ratio, CI: Confidence Interval, Ref: Reference Value

Table 5: Distribution of dental injuries according to the classification of Elis modified by Fried among gender.

\begin{tabular}{|c|c|c|c|c|c|c|c|}
\hline \multirow{3}{*}{ Classes } & \multicolumn{4}{|c|}{ Gender } & \multirow[t]{3}{*}{ Total } & \multirow[t]{3}{*}{$\mathbf{X}^{2}$} & \multirow[t]{3}{*}{$P$-value } \\
\hline & \multicolumn{2}{|c|}{ Male } & \multicolumn{2}{|c|}{ Female } & & & \\
\hline & Freq. & $\%$ & Freq. & $\%$ & & & \\
\hline Class I & 68 & 85.0 & 12 & 15.0 & 80 & & \\
\hline Class II & 47 & 21.9 & 9 & 16.1 & 56 & & \\
\hline Class III & 2 & 66.6 & 1 & 33.3 & 3 & & $\Omega^{*}$ \\
\hline Class IV & 9 & 81.8 & 2 & 18.2 & 11 & 1.19 & 0.9 \\
\hline Class V & 3 & 75 & 1 & 25 & 4 & & \\
\hline Class VI & 1 & 100 & 0 & 0.0 & 1 & & \\
\hline
\end{tabular}

Most of the children who had dental injuries in this study had only one damaged teeth, 103 out of 155 infected teeth (Table 3), and the most affected teeth are maxillary central incisors $(82.45 \%)$ (Figure 3$)$. This result coincides with previous studies ${ }^{12,15,18,19,30-32}$. Perhaps this vulnerable position relates to maxillary central incisors. In addition, these teeth are often protruded and may have insufficient lip coverage ${ }^{24}$. The study showed that the prevalence of dental injuries increases with the age of 7 to 12 years. The highest exposure to dental trauma occurred in sixth grade $(32.56 \%)$. The distribution of children's age groups showed that the highest prevalence of dental trauma occurred in the 10-12 age group (16.5\%) out of 635 , followed by the 7-9 years $(3.9 \%)$ age group of 617 (Table 4). The results showed statistically significant differences between groups, consistent with other studies $^{20,33,34}$. The incidence of dental injuries increases during the very active age range because of bicycle riding, skateboarding, and playground and sports accidents ${ }^{35}$. Regarding the trauma site, most TDI occurred on the street (Figure 1). For males (44.9\%), this may be due to the presence of a lot of devastating holes and platforms on the streets during play time. In addition, most of the fighting between males took place on the street, causing students to fall, while for females most injuries occurred at home $(31.81 \%)$ due to Yemeni society traditions that disagree with spending females outside their times as homes. Moreover, the results revealed a significant statistical correlation between sex and place of injuries among children (Figure 1). This finding is consistent with other studies $^{36,37}$, whereas in other studies ${ }^{18,21,32,38}$ most of the injuries occurred at home. In the current study, the most common cause of trauma was falls $(62.01 \%)$ for both sexes (Figure 2). This result was according to many previous studies ${ }^{18,30,31,39,40}$ that mentioned the particular importance of health policy makers for developing preventive strategies to reduce facial injuries or trauma. The main activities that caused the fall of children were play, cycling, running and other activities.

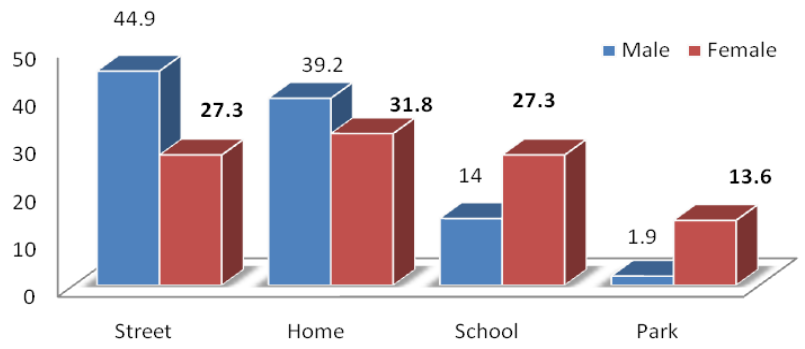

Figure 1: Distribution of trauma according to gender and location of injuries among schoolchildren.

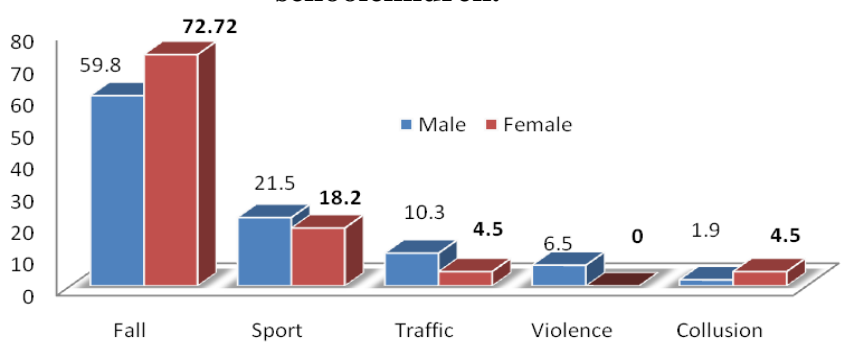

Figure 2: Bar chart showed distribution of trauma according to gender and cause of injury among schoolchildren. 
The percentage of injuries resulting from sports activities $(20.93 \%)$. This result can be explained by the fact that sports facilities are not widely available to schoolchildren in Sana'a schools. Violence was found in the current study to be the cause of dental trauma in males but not females. This is generally due to the privacy of Yemeni society. However, other previous studies, specifically Bastone et al., ${ }^{41}$; and Vuković et al., ${ }^{42}$ studies showed that accidents for adolescents were the chief cause of traumatic teeth.

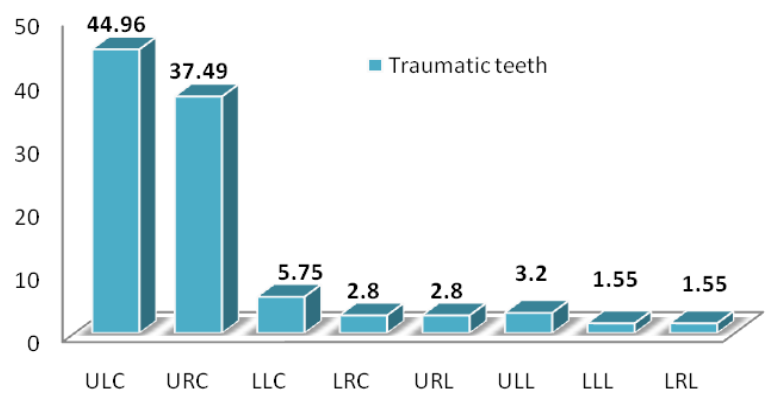

Figure 3: Distribution of trauma in relation to affected teeth among schoolchildren.

ULC: Upper left central incisor, URC: Upper right central incisor,

LLC: Lower left central incisor, LRC: Lower right central incisor,

URL: Upper right lateral incisor, ULL: Upper left lateral incisor,

LLL: Lower left lateral incisor, LRL: Lower right lateral incisor

Concerning the distribution of dental injuries in this study according to the classification of Ellis modified by Fried, class I (enamel fracture) as the most common type of fracture and accounted for $(51.6 \%)$ of the total fractures, followed by class II fractures involving (enamel-dentine) with (36.1\%) (Table 5). These results were in accordance with most of the previous studies ${ }^{16}$, 20,30,43. While a few other studies have shown that the class II is the most common type of fracture $29,32,36,40$. Total traumatized teeth were 155 as shown in (Figure 3). This result disagrees with study by Akinyamoju et al., ${ }^{44}$, because serious impacts, for instance those resulting from traffic accidents, may proliferate the number of teeth involved with periapical lesion, which are better represented in hospital and institution-based studies ${ }^{45}$. As the present study was conducted in schools and not in the hospitals, less severe cases involving only enamel fractures were more evident.

\section{CONCLUSION}

In conclusion, the prevalence of traumatic dental injuries to permanent anterior teeth among mixed dentition of schoolchildren in Sana'a City was high, higher in males than in females, falling was the common cause of trauma, followed by sports in both genders. The peak age DTI was between 10 to 12 years old, most injuries occurred at street for males and at home for females. Most of the children who experienced dental injuries had only one tooth damaged, and the most commonly affected teeth were the maxillary central incisors and Class I. Therefore, educational programs should be developed that focus on ways to prevent dental trauma and the benefits of seeking immediate treatment to keep avulsed and fractured teeth. These programs should be targeted at the community level as well as in schools. Ongoing educational programs on the latest techniques in trauma dental management should also be arranged for dental and medical practitioners.

\section{ACKNOWLEDGMENTS}

Authors acknowledge the financial support of Sana'a University, Yemen.

\section{CONFLICT OF INTEREST}

No conflict of interest associated with this work.

\section{AUTHOR'S CONTRIBUTION}

This research work is part of a Master's thesis. The candidate is the first author (NJM) to conduct clinical work and thesis. Corresponding author (HAA), second author (KAA) and the rest of authors supervised the work, revised and edited the thesis draft and the manuscript.

\section{REFERENCES}

1. Hegde R, Agrawal G. Prevalence of Traumatic Dental Injuries to the Permanent Anterior Teeth among 9- to 14year-old Schoolchildren of Navi Mumbai (KhargharBelapur Region), India. Int J Clin PedDent 2017; 10 (2): 177-182.https://doi.org/10.5005/jp-journals-10005-1430

2. Petersson EE, Andersson L, Sörensen S. Traumatic oral and non-oral injuries. Swed Dent J 1997; 21(12): 55-68. PMID: 9178450

3. Welbury R, Duggal M. Paediatric dentistry. Text book, Oxford. 2005, $3^{\text {rd }}$ ed: 320.

4. Glendor U. Etiology and risk factors related to traumatic dental injuries--a review of the literature. Dent Traum 2009; 25: 19-31. https://doi.org/10.1111/j.1600-9657.2008.00694.x

5. Madhwani SS, Nadeem M, Najmi N, Qureshi NR, Datoo F. Traumatic dental injuries in mixed dentation of school going children in Karachi, Pakistan. Int J Dent Clin 2014; 6 (3): 7-9.

6. Cavalcanti AL, Bezerra PK, de Alencar CR, Moura C. Traumatic anterior dental injuries in 7- to 12-yearold Brazilian children. Dent Traumatol 2009; 25: 198-202. https://doi.org/10.1111/j.1600-9657.2008.00746.x

7. Artun J, Behbehani F, Al-Jame B, Kerosuo H. Incisor trauma in an adolescent Arab Population. Prevalence, severity and occlusal risk factors. Am J Orthod Dentof Orthop 2005; 128: 347-52. https://doi.org/10.1016/j.ajodo.2004.06.032

8. Traebert J, Bittencourt DD, Peres KG, Peres MA, de Lacerda JT, Marcenes W. Aetiology and rates of treatment of traumatic dental injuries among 12 years-old schoolchildren in a town in southern Brazil. Dent Traumatol 2006; 22 : 173-8. https://doi.org/10.1111/j.1600-9657.2006.00359.x

9. Fontenele M, Macedo M, Rebouças P, et al. Sequelae in primary teeth after traumatic injury. Brazil Dent Sci 2017; 20 (2): 70-75 https://doi.org/10.14295/bds.2017.v20i2.1350

10. Mattila ML, Rautava P, Ojanlatva A, Paunio P, Hyssala L, Helenius H, Sillanpaa M. Will the role of family influence dental caries among seven-year-old children? Acta Odontol Scand 2005; 63: 73-84. https://doi.org/10.1080/00016350510019720

11. McIntyre JD, Lee JY, Trope M. Vann WF Jr. Effectiveness of dental trauma education for elementary school staff. Dent Traumatol 2008; 24(2): 146-150. https://doi.org/10.1111/j.1600-9657.2008.00573.x

12. Dua R, Sharma S. Prevalence, causes, and correlates of traumatic dental injuries among seven-to-twelve-year-old school children in Dera Bassi. Contemp Clin Dent 2012; 3(1): 38-41. https://doi.org/10.4103/0976-237X.94544 
13. Ellis GE, Davey KW. The classification and treatment of injuries to the teeth of children. Chicago, $5^{\text {th }}$ ed Year Book Medical Publishers; 1970.

14. Patel MC, Sujan SG. The prevalence of traumatic dental injuries to permanent anterior teeth and its relation with predisposing risk factors among 8-13 years school children of Vadodara city: An epidemiological study. J Indian Soc Pedod Prev Dent 2012; 30(2); 151-157. https://doi.org/10.4103/0970-4388.99992

15. Al Akwa. Clinical and radiographic study of the prevalence of traumatic injuries to the permanent incisors among group of Egyptian and Yemeni school children, ph. D. 2009 .

16. Noori AJ, Al-Obaidi WA. Traumatic dental injuries among primary school children in Sulaimani city, Iraq. Dent Traumatol 2009; 25(4): 442-6. https://doi.org/10.1111/j.1600-9657.2009.00791.x

17. Gupta S, Kumar-Jindal S, Bansal M, Singla A. Prevalence of traumatic dental injuries and role of incisal overjet and inadequate lip coverage as risk factors among 4-15 years old government school children in Baddi-Barotiwala Area, Himachal Pradesh, India. Med Oral Patol Oral Cir Bucal 2011; 16(7): 960-5. https://doi.org/10.4317/medoral.17265

18. Rajab LD, Baqain ZH, Ghazaleh SB, Sonbol HN, Hamdan MA. Traumatic dental injuries among 12-year-old school children in Jordan: prevalence, risk factors and treatment 'need. Oral Health Prev Dent 2013; 11(2): 105-12. https://doi.org/10.3290/j.ohpd.a29362

19. Lam R. Epidemiology and outcomes of traumatic dental injuries: a review of the literature. Aust Dent J 2016; 61 1: 4-20. https://doi.org/10.1111/adj.12395

20. Govindarajan M, Reddy VN, Ramalingam R, Durai KS, Rao PA, Prabhu A. Prevalence of traumatic dental injuries to the anterior teeth among three to thirteen-year-old school children of Tamilnadu. Contemp Clin Dent J 2012; 3(2): 164-167. https://doi.org/10.4103/0976-237X.96819

21. Kulkarni S, Raje S. Prevalence of traumatic dental injuries and their relation with predisposing factors among 8-15 years old school children of Indore city, India. Clujul Med 2018; 91(3): 328-335. https://doi.org/10.15386/cjmed-898

22. Ogordi PU, Ize-Iyamu I N, Adeniyi E O. Prevalence of traumatic dental injury to the anterior teeth in children attending paramilitary and non paramilitary schools. Ann Afr Med 2019; 18: 80-5 https://doi.org/10.4103/aam.aam_27_18

23. Traebert J, Almeida IC, Marcenes W. Etiology of traumatic dental injuries in 11 to 13-year-old schoolchildren. Oral H Prev Dent 2003; 1(4): 317-23. PMID: 15643760

24. Marcenes W, Murray S. Changes in prevalence and treatment need for traumatic dental injuries among 14year-old children in Newham, London: a deprived area. Community Dent Health 2002; 19(2): 104-8. PMID: 12146578

25. Aldrigui JM, Jabbar NS, Bonecker M, Braga MM, Wanderley MT. Trends and associated factors in prevalence of dental trauma in Latin America and Caribbean: A systematic review and meta-analysis. Community Dent Oral Epidemiology 2014; 42: 30-42. https://doi.org/10.1111/cdoe.12053

26. Al-Bajjali TT, Rajab LD. Traumatic dental injuries among 12-year-old Jordanian school children: an investigation on obesity and other risk factors. BMC Oral Health 2014; 4: 101. https://doi.org/10.1186/1472-6831-14-101

27. Oyedele TA, Jegede AT, Folayan MO. Prevalence and family structures related factors associated with crown trauma in school children resident in suburban Nigeria. BMC Oral Health 2016; 16: 116 https://doi.org/10.1186/s12903-016-0314-9

28. Ravishankar TL, Kumar MA, Ramesh N, Chaitra TR. Prevalence of traumatic dental injuries to permanent incisors among 12-year-old school children in Davangere,
South India. Chin J Dent Res 2010; 13(1): 57-60. PMID: 20936193

29. Rajesh A , Vijay T, Raksha B. Traumatic Injuries to Anterior Teeth in School Children of Southern India, Indian J Dent Educ 2012; 5 :2.

30. Ain TS, Lingesha Telgi R, Sultan S, et al. Prevalence of traumatic Dental injuries to anterior teeth of 12-yearold school children in Kashmir, India. Arch Trauma Res 2016; 5(1):12. https://doi.org/10.5812/atr.24596

31. Sharma S, Shahi AK, Mukhopadhyay M, Jha A. Traumatic dental injuries and associated risk factors of anterior teeth in eight to thirteen years (8-13yrs) old school children of Patna Bihar - a prevalence study. I J C Medical Research 2016; 3(3): 906-910.

32. Škaričić J, Vuletić M, Hrvatin S, et al. Prevalence, type and etiology of dental and soft tissue injuries in children in Croatia. Acta Clin Croat 2016; 55(2): 209-16. https://doi.org/10.20471/acc.2016.55.02.05

33. Chen Z, Si Y, Gong Y, Wang JG, Liu JX, He Y, et al. Traumatic dental injuries among 8-to 12-year-old schoolchildren in Pinggu District, Beijing, China, during 2012. Dent Traumatol 2014; 30: 385 -90. https://doi.org/10.1111/edt.12110

34. Tumen EC, Kaya S, YavuzI, Uysal E. Prevalence of traumatic dental injuries and associated factors among 8 to 12-years-old schoolchildren in Diyarbakir, Turkey. Nigerian J Clinl Pract 2017; 20(10): 1259. https://doi.org/10.4103/1119-3077.219518

35. Singh G, Garg S, Gangaramji Damle S, Dhindsa A, Kaur A. A study of sports related occurrence of traumatic orodental injuries and associated risk factors in high school students in North India. Asian J Sports Med 2014 ; 5(3):1-5. https://doi.org/10.5812/asjsm.22766

36. Rodrigues CST, Risso P de A, Maia LC. Traumatic dental injury in permanent teeth of young patients attended at the federal University of Rio de Janeiro, Brazil. Dent Traumatol 2014; 30(4): 312-6. https://doi.org/10.1111/edt.12087

37. Paiva PCP, Neves H de, Messias P de, Filhoe O, Côrtes MI S de. Prevalence and risk factors associated with traumatic dental injury among 12-year-old schoolchildren in Montes Claros. Brazil. Sci ELO Analy J 2015; 20 : 4. https://doi.org/10.1590/1413-81232015204.00752014

38. Azami-Aghdash S, Ebadifard Azar F, et al. Prevalence, etiology, and types of dental trauma in children and adolescents: systematic review and meta-analysis. Med J Islam Repub Iran 2015; 29(4): 234. PMID: 26793672

39. Toprak ME, Tuna EB, Seymen F, Gençay K. Traumatic dental injuries in Turkish children, Istanbul. Dent Traumatol 2014; 30(4): 280-4. https://doi.org/10.1111/edt.12092

40. Kallel I, Douki N. Epidemiology of traumatic dental injuries in Tunisia: A prospective study. Afr $\mathbf{J}$ Trauma 2015; 4: 51-6.

41. Bastone EB, Freer TJ, McNamara JR. Epidemiology of dental trauma: A review of the literature. Aust Dent 2000 J; 45(1): 2-9. https://doi.org/10.1111/j.1834-7819.2000.tb00234.x

42. Vuković A, Marković D, Petrović B, et al. Traumatic dental injuries in Serbian children--epidemiological study. Srp Arh Celok Lek 2013; 141(11-12): 744-9. https://doi.org/10.2298/sarh1312744v

43. Al-Majed I, Murray JJ, Maquire A. Prevalence of dental trauma in 5-6 and 12-14 years old boys in Riyadh, Saudi Arabia. Dent Traumatol 2001(4): 153-8. https://doi.org/10.1034/j.1600-9657.2001.170403.x

44. Akinyamoju AO, Gbadebo SO, Adeyemi BF. Periapical lesions of the jaws: A review of 104 cases in Ibadan. Ann Ib Postgrad Med 2014; 12(2): 115-9. PMID: 25960702

45. Guedes OA, Alencar AH, Lopes LG, et al. A retrospective study of traumatic dental injuries in a Brazilian dental urgency service. Dent Traumatol 2010; 21(2): 153-7. https://doi.org/10.1590/s0103-64402010000200011 